\title{
Pride and prejudice in teaching History in Brazil: Reflections about the curricula, teacher training and textbooks ${ }^{\mathrm{I}}$
}

\author{
Orgulho e preconceito no ensino de História no Brasil: reflexões sobre currículos, \\ formação docente e livros didáticos
}

\author{
Giovani José da Silva * \\ Marinelma Costa Meireles ** \\ Traduzido por Gabriela Edel Mei
}

\begin{abstract}
In a historical moment in which we've been discussing about an elaboration of a National Curricular Common Base for the Basic Brazilian Education, reflections about teachers training, curricula and textbooks are necessary. With a few variations, the Teaching History in Brazil is still ruled by the Eurocentrism, through the idea of the History of a country is a derivation of the European expansion and by the denial of the protagonism of indigenous populations, Africans and their descendants, as well as other peoples. The recent clashes between professional historians, History teachers, and education specialists in the school curriculum component show that there are different conceptions in dispute about what students in Brazil should learn about History. The purpose of the text is to problematize such situation, questioning and presenting alternatives to combat racism in History Teaching in Brazil so that the young Brazilians who finish their studies in Basic Education be proud of their origins. Curricula that present a linear history, in stages and with evolutionary characteristics, as well as teacher training courses and didactic materials that crystallize and consecrate only a European version of History make it impossible to change the status quo.
\end{abstract}

\footnotetext{
I The title of the article refers to Jane Austen's Pride and Prejudice (I8I3). One of the most important themes in Austen's work is the importance of the environment in the development of young people. The authors chose the title in order to present reflections on the importance of overcoming racism in the Brazilian school environment, especially in History classes, so that the new generations, free of prejudice, will be proud of their black, indigenous origins, migrants.

* Universidade Federal do Amapá (Unifap)/ Campus Marco Zero do Equador and Universidade Federal Fluminense (UFF). Doctor in History and Scholarship holder of CNPq (Post-Doctorate Senior).

** Federal Institute of Education, Science and Technology of Maranhão (IFMA) / Barreirinhas Campus and Federal University of Pará (UFPA). Master in History.
} 
Keywords: History Teaching, Curricula and Teacher Training, Textbooks

Resumo: Em um momento histórico no qual se discute a elaboração de uma Base Nacional Comum Curricular para a Educação Básica brasileira, reflexões sobre formação de professores, currículos e livros didáticos de História são necessárias. Com poucas variações, o Ensino de História no Brasil ainda é pautado pelo eurocentrismo, pela ideia de que a história do país é uma derivação da expansão europeia e pela negação do protagonismo de populações indígenas, africanas e seus descendentes, além de outros povos. Os recentes embates verificados entre historiadores profissionais, professores de História e especialistas em Ensino do componente curricular escolar mostram que há diferentes concepções em disputa sobre o que os alunos no Brasil devam aprender sobre História. O objetivo do texto é problematizar tal situação, questionando e apresentando alternativas para combater o racismo no Ensino de História no Brasil e que jovens brasileiros que terminam sua formação na Educação Básica tenham orgulho de suas origens. Currículos que apresentam uma história linear, por etapas e com características evolucionistas, bem como cursos de formação de professores e materiais didáticos que cristalizam e consagram apenas uma versão europeia da História, tornam tarefa impossível a mudança do status quo.

Palavras-chave: Ensino de História, Currículos e Formação docente, Livros didáticos

\section{Initial considerations}

In a historical moment in which the elaboration of a National Curricular Common Base (BNCC) for the Brazilian Basic Education is discussed, reflections on teacher training, curricula and textbooks on History become necessary and even urgent. With a few variations, History Education in Brazil is still guided by Eurocentrism, by the idea that the history of the country is only a derivation of the so-called European expansion and by the denial of the protagonism of indigenous populations, African and their descendants, as well as other peoples which, over time, formed the current Brazilian population. The recent clashes between professional historians, history teachers, and education specialists in the school curriculum component show that there are differing conceptions in dispute about what a child or a young man in Brazil should learn about history. 
If most of the Brazilian population is evidently made up of self-declared blacks and browns (BRASIL, 20I0), how can education courses, curricula, and textbooks continue to present narratives mainly destined to the understanding of the space-time trajectories of Europeans? Black, indigenous and other non-European populations appear (when they appear) only as "appendices", in a history in which they are now a "problem" to be equated, sometimes they are parts of the colonial gear and still seen as a "obstacle" to the progress and development of the newly formed Brazilian Nation in the nineteenth century. The curricular matrices of undergraduate courses in History still work with the quadripartite division, invented by the French almost two centuries ago, and curricula of states and municipalities in Brazil, in addition to textbooks, consecrate such a version (PORTO, 2007).

The objective of this text is to problematize this, questioning and presenting alternatives so that racism is definitely overcome in History Teaching in Brazil and that the Brazilian young people who finish their education in Basic Education are proud of their origins. Curricula that present a linear history, in stages and with evolutionary characteristics, as well as teacher training courses and didactic materials that crystallize and consecrate only a European version of History make it impossible to change the status quo. The argument that a Brazilian child has the right to the knowledge of the history of Humanity, in fact, eschews the idea that history only comes from the Europeans, considered "civilized", "superior" and therefore seen as models of "progress" and "development".

These issues were strongly evidenced when the authors of the article participated in the Committee of experts appointed by the Ministry of Education (MEC) for the BNCC discussion. From the internal attacks on the Commission to the strong criticism from different social groups (universities, scientific associations, the press, etc.), after the publication of the first version of the document, much has yet to be reflected and done with regard to teacher training. The reflections necessarily involve a discussion of the locus of indigenous, African and Afro-descendant populations in school history and historiography, as well as the role they occupy and occupied in the historical / historiographic narratives that constructed the images, representations and identities of Brazilians and Brazilians over time.

The existence of law no. II,645/2008 (as well as the previous one, Law No. I0.639/2003) did not guarantee by itself that African, Afro - Brazilian and indigenous histories and cultures were included as protagonists in the various school curriculum components, notably History (RUSSO, PALADINO, 20I4). Without demeaning the law and 
the struggles that were fought until its promulgation, what is happening in Brazilian schools is the continuity of practices that reserve space and time for the treatment of diversity themes, such as "Black Awareness Week" or "Indian Day" projects, in a timely, superficial and non-reflective way. History classes in Basic Education and Higher Education, in general, continue to be characterized by a disguised racism, in which Brazilian children and young people, victims of prejudices of all kinds, learn to be ashamed of their black, indigenous, migrant roots.

\section{Racism and prejudice in History Teaching in Brazil}

If one is asked to take an undergraduate course in history from any region of the country at the beginning of the twenty-first century, on how the curricular matrix that bases his formation as a future professor historian is structured, he will invariably say that he studies History of America, History of Brazil, History Theory, and others. What he probably will not say is that he studies a lot of history in Europe. In fact, the young man in question should have no discipline with such nomenclature, but the history of the Old World is massively presented to him and his colleagues, but with other names: Ancient, Medieval, Modern and Contemporary History. There are those who claim that it is not possible to study History without these beacons, because, after all, Brazil was colonized by Europeans who bequeathed their customs, language, religion, and so on.

The absence of women, children, the elderly, homosexuals and so many other people in History Education, or in Basic Education or Higher Education in Brazil is remarkable. Future teachers of history, for example, are taught, in universities and colleges, the trajectories of adult, white, and colonizing men. In short, there are those who believe that the history of the lands and people of what would come to be called Brazil only began with the arrival of those who brought the Law, the Faith and the King. The absence of diversity, the consecration of certain themes that have become canonical over time, and the European omnipresence in the historical / historiographic narratives in Brazil point to a racist, homophobic, misogynist, macho formation. These characteristics form the Brazilian reality experienced by teachers and students in a contemporary daily life strongly marked by violence, inequality and its harmful consequences.

Prejudices are also learned in school, which replicates the structure of the society in which it is embedded. Although it should not occur, hardly an academic who graduates in history with a Eurocentric curricular matrix will reproduce in his classes something 
different from what he was taught as correct. Brazilian society is racist, but it does not see itself in this way and it does not accept that the subject is treated as a serious problem to be definitively overcome. The same thing happens with teachers of History: many of them do not see their ideas as prejudices or their attitudes as discriminatory. To prove that they are not, they use arguments such as the realization of projects in the school environment that refer to indigenous, Afro-Brazilian and African populations during the school year, as advocated by law.

However, as Edson Brito warns, about projects that seek to insert the indigenous theme in schools:

[...] it is observed that in non-indigenous schools, indigenous peoples are portrayed as the expression of national folklore or as elements attached to a distant past in Brazilian history. They are remembered in the colonial period classes and eventually in other moments of national history or in the demonstrations of April 19, when the children leave the school with their faces painted or with a feather of cardboard attached to the head. In this perspective the culture of indigenous peoples is doomed to extinction and the present time does not belong to them. (BRITO, 2009, p. 6I)

Such projects often lend themselves only to "including" certain "contents" and are not thought of and executed in a global, systemic and interdisciplinary way. Although they comply, partially and precariously, with law II.645/2008, they do not reach the objective of discussing and overcoming racism in school and out-of-school environments, since they induce folklore, exoticism and stereotyping of African, and Afro-Brazilian. Many teachers will say that they did not have access to such information in their history training courses. This is true, but this situation will not be solved only by the inclusion of one or two subjects of History of Africa and of Indigenous History, nor of Education for ethnic-racial relations, in the curricular matrices of History of Brazilian Higher Education.

Pedagogical rituals, such as the presentation of "transvestite" students as indigenous on April I9 or the presentation of enslaved black characters, breaking up cardboard chains on November 20, do not definitively help to change the situation of racism and violence experienced by all in schools. It is necessary to do more than this, even problematizing the representations and uses that are made of the past and the identities of indigenous and black populations in Brazil. The absence of diversity in curricula and teaching materials thus reflects the mistaken idea that "good comes from outside", for example, from Europe, 
generating shame and low self-esteem in children and young people who could have pride and respect for their own space-time trajectories and the trajectories of their ancestors.

It can be seen that regional/local histories that escape the narratives referring to the Brazilian Center-South are despised and are not found in nationally distributed textbooks, nor in teacher training courses and state and municipal curricula. How can students and teachers of Maranhão, for example, be expected to recognize themselves in texts and images that relate to events occurring in the Rio-São Paulo axis, even though such narrative is also part of the historical formation of the country? It is not being proposed the exchange of a history for another, but the problematization of the primacy of a certain history over others. What is seen in Brazil in relation to the formation of History teachers, didactic literature and curricula is the supremacy of a certain version of History, which would have started with the "primitive" cavemen (notably in Europe, to the detriment of emergence of mankind in Africa) and extending until the arrival of man on the Moon, symbol of the apogee of development and progress of Humanity.

As well noted by Anderson Ribeiro Oliva (2003, p. 437):

[...] it must be emphasized that history, at that time [nineteenth century], had come to be confused with two elements: national trajectories understood as the chronological inventories of the main political facts of European states, almost always carried out by illustrious figures or heroes; and with the rectilinear and natural movement toward technological and civilizational progress. In this way, the idea of transformation, of the constant search for the new, for the modern, would become an obsession. Moreover, due to methodological rigor, the past could only be accessed with the use of official written documents.

Observed from this historical perspective, the African peoples did not play a prominent role in the history of humanity.

Who, after all, determines in Brazil what "content" to be taught by the history teacher? We know of the power and influence that textbook publishers exercise over what should or should not be taught in Brazilian schools. Thus, it can be affirmed that, at least since the second half of the 2oth century, curricula, courses of teacher training and teaching materials (GATTI JÚNIOR, 2004) were drawn from a consecrated vision of history, divided into four parts related to political events predominantly occurring in European lands. Even when the subject is the History of Brazil the chronological beacons 
are given exclusively by political events and for that reason there is History of Brazil Colony, Brazil Empire and Brazil Republic. The narratives referring to the indigenous and African populations conform to what is traditionally known as "Prehistory", that is, they reaffirm the idea that such populations are outside the history of Humanity. The debates that arose from the elaboration of the BNCC, carried out between 2015 and 20I6, tried, with little success, to break with such traditions and canons.

\section{Reflections on the curriculum of History: The National Common Curricular Base}

Made up of II6 members from all the states of the Brazilian Federation, the Committee of experts for the elaboration of BNCC proposal was instituted by Ordinance n. I9 of July IO, 20I5, signed by the Secretary of Basic Education of the Ministry of Education, Manuel Fernando Palácios da Cunha e Melo. Of the more than one hundred experts named, twelve were from the History curricular component: Antônio Daniel Marinho Ribeiro (Seduc-AL); Giovani José da Silva (Unifap, erroneamente grafada como Ufap); Leandro Mendes Rocha (UFG); Leila Soares de Souza Perussolo (Undime-RR); Márcia de Almeida Gonçalves (Uerj); Maria da Guia de Oliveira Medeiros (Undime-RN); Marcos Antonio da Silva (USP); Marinelma Costa Meireles (Seduc-MA); Reginaldo Gomes da Silva (Seduc-AP); Rilma Suely de Souza Melo (Seduc-PB); Sandra Regina Ferreira de Oliveira (UEL); Tatiana Gariglio Clark Xavier (Seduc-MG). Of these names, ten specialists remained in the committee, retiring the teachers Márcia Gonçalves and Sandra Oliveira.

Throughout the work, other specialists were incorporated into the committee to assist in the elaboration of the document related to the History curricular component: Claudia Regina Fonseca Miguel Sapag Ricci (Pedagogical Center-UFMG); Itamar Freitas de Oliveira (UnB); Margarida Maria Dias de Oliveira (UFRN); Mauro Cezar Coelho (UFPA). Claudia Ricci was appointed advisor to the group of experts, a role she held from June 2015 to April 20I6. The group was made up of fourteen experts, with seven representatives from universities (UFG, UFMG, UFPA, UFRN, UnB, Unifap and USP), five representatives appointed by the Consed (National Council of Secretaries of Education) Alagoas, Amapá, Maranhão, Minas Gerais and Paraíba, two representatives ofcUndime (National Union of Municipal Education Directors) - Rio Grande do Norte and Roraima.

It can be noticed that the composition of the group was quite heterogeneous and diversified, feeling the absence of specialists from the Brazilian South. There was a certain predominance of the North / Northeast, with the presence of representatives of seven states 
from those regions, shifting the Commission's view of the great Rio-São Paulo axis to areas previously considered academically "peripheral". Still with regard to the composition of the team, gender equity was observed (seven men and seven women), which did not mean a break with the more traditional view of history in several senses and nor the inclusion of themes of gender diversity and sexualities in the first version of the document. Of the fourteen specialists, half were from universities, having been invited by the MEC, unlike those who were nominated by Consed and Undime. There were no specialists by area or sub-area (History of America, Modern History, etc.) and, in this aspect, neither the concern to contemplate the already consecrated by Historiography.

The Commission was formed in compliance with the provisions of the National Education Plan (PNE), which establishes guidelines, targets and strategies for the Brazilian educational policy of the next ten years, from the year in which it was sanctioned, that is, from 2014 to 2024. The BNCC is part of the goals to be achieved by states, municipalities and the Union. The discussions on the construction of the proposal of the National Curricular Common Base began in February 2015, starting with meetings with a limited number of specialists, called area assessors. At that time there was no adviser appointed for the History component, since the advisory services were thought by area of knowledge. Thus, the area of Human Sciences was the responsibility of Marisa Teresinha Rosa Valadares (UFF) and Marcelo Tadeu Baumann Burgos (PUC-RJ). With the publication of the ministerial decree already mentioned and another, which appointed advisors for each curricular component (no. 20 of IO July 20I5), the work of the Commission has been initiated and three major seminars have been held with the participation of all experts.

A first version was launched via Portal on the Internet on September I6, 2015, without containing the proposal of the curricular component History. This had already revealed the internal conflicts between members of the Commission itself and between the Commission and the MEC, which was pressing for a lack of mention of gender diversity and sexuality, and to reduce references to the history of indigenous peoples, Africans and Afro-Brazilians, to the detriment of a more traditional view. It was questioned, for example, absence of canonical facts, such as the Minas Gerais Conspiracy (1789), and, internally, there were members of the Commission who preached that the History of Brazil would only begin with the arrival of the Portuguese. Hastily modified, the first version of the proposal of History was published a few days later and began to suffer a flood of criticism, 
be it from scientific associations, specialists in History Teaching, Basic Education teachers and professional historians.

The most emblematic case may be that of Professor Ronaldo Vainfas, from the Fluminense Federal University, who harshly questioned the work of the Commission in an article signed for the newspaper O Globo, titled "New face of authoritarianism" (VAINFAS, 2015), published on June 6. December 20I5. In the article, Professor Vainfas calls the first version for the curricular component History in the BNCC of "aberration", emphasizing that the proposal would mutilate the global historical processes, besides betting on the synchrony against the diachrony. Irrespective of the personal criticism contained in the article, there are a series of inaccuracies and inaccuracies posed by the eminent historian that need to be problematized, especially in relation to History Teaching in Brazil throughout the 2oth century and in relation to the specialists who were part of the Commission.

For Vainfas, the proposal would be fanatical by presentism, encouraging racial hatreds and overcome third-world values; would stimulate ignorance by placing Western history as peripheral as villain. In addition, it would counteract Eurocentrism with an inconsistent "Brazil-centrism", among other serious problems. To the acknowledged professor of History of America, however, there seems to be no problem that the History of Brazil remains "peripheral" for Brazilian students and pupils. Ask if: who, after all, would stimulate racial hatred but the didactic materials, omnipresent in Brazilian schools, that bet on a history of colonizers, predominantly political and made by adult and white men? It is emphasized that the critic himself signs textbooks that present the consecrated version of History and that, although author of works that refer to the indigenous populations in the colonial period (VAINFAS, 1992, 1995), such characters are not protagonists of didactic narratives proposed by him and his coauthors (CALAINHO; FERREIRA; VAINFAS; FARIA, 20I5).

In the critique there are inaccuracies regarding the curricular matrices of History of the I970s and I980s in Brazil. Professor Vainfas still reveals ignorance of the ordinance that appointed the Commission of specialists, their names and institutions of origin, as if it had done something secret since it was formed. Correcting it, the Commission was constituted in 2015 and not in 2014 as written in the article.

It is even questioned whether the historian imagines that his didactic works do not have the same claim to presume a standardization of historical knowledge in Basic Education, an accusation made by him to the Commission. When the critic categorically 
asserts that it is impossible to teach a child concepts/category such as subjects and processes, would not he be belittling the cognitive ability of professors and students? If the first version presented by the Commission was really based on the History of Brazil for Elementary School - Final Years, it is questioned that the textbooks signed by the critic put too much emphasis, like practically all the others, on European history.

The dialogue with Professor Vainfas's critique prompts a discussion about who, after all, are the voices that have the "authoritative language" (ORTIZ, I983; BOURDIEU, I996) to utter "competent discourses" (CHAUÍ, I98I) on Teaching History in Brazil. If there were so-called History Teachers on the one hand and teachers of Basic Education on the other, it would not be surprising if there was a polarization in the debates that followed the publication of the first version of History of the BNCC. The proposal for this version, however, was open to public discussion and there was no intention at any time to disregard the innumerable contributions received from teachers, specialists and technicians. The BNCC Portal also presented the possibility of interaction with all those interested in discussing the basic curricula for Brazilian Education.

Jean Carlos Moreno, criticizing the first version of the BNCC's History document, points out that:

To understand the proposal of History and its repercussions it is necessary to go beyond and to notice that the text of the BNCC dialogues with a curricular reality, established by tradition, in a format that acquired stability in the early I990s and, even with state curricular revisions or remains hegemonic. It is a chronologically organized curriculum based on a principle known as integrated history that is repeated at different levels of education. In this organization, a history of "civilization" occupies more space in the school environment, to the detriment of the History of Brazil and America. (MORENO, 20I6, p. I5)

Also, critical, the text published on the Internet by the historian Hebe Mattos (2015), in early December 20I5, professor of the same university that Ronaldo Vainfas, pointed some interesting and propositive ways to the Committee of experts. By examining problems which had already been detected by the Commission's own experts - "[...] the effort to free itself from the Eurocentric organization of history has largely resulted in a difficulty in historically addressing the centrality of European expansion to the very construction of a 'History of Brazil' "- Mattos acknowledged the efforts to try to break with 
the hegemonic and predominant model in History Teaching and also warned of the obligation to teach Afro-Brazilian, African and indigenous history and cultures, as the law advocates. It should be noted, however, that there was no consensus on such issues even among the II6 members of the Commission, since only history had decided to address such issues.

It is misleading who thinks that there was no conflict within the Commission that proposed the first version of BNCC, starting with the position of the adviser of the curricular component History, which flatly rejected, without debates and discussions, any proposal of curricular matrix elaborated from chronological beacons. The authors of this article have problematized this position, as well as combating some ideas that have emerged during the debates, such as that the history of what would become Brazil begins only with the arrival of the Portuguese in the Americas. A second version was elaborated, which contemplated the many suggestions sent by professors from all over Brazil, as well as referees invited by the MEC to evaluate the proposal.

It should be noted that the most voracious and ferocious critics did not start from sectors of the so-called "right" in Brazil. The greatest critics of the first version (since the second was not published as the Commission had elaborated) were teachers of History, Basic Education to Higher Education, specialists in History Teaching and technicians of a government considered to be "left". The criticisms received from all sides were not generally suggestive, nor did they indicate new paths to be followed, beyond those already consecrated by the historiographical canon. Although the suggestions of countless professionals specialized in several areas or subareas of History to rethink the national curriculum have been accepted, it was desired to rethink the learning rights of Brazilian students and students. Why would it be more important for a black student to know the Greek philosophers than the history of his African ancestors, for example?

The second version of BNCC proposed by the Commission, or what remains of it ${ }^{2}$, after the departure of university experts, except for professors Giovani Silva and Leandro Rocha, was radically altered without the knowledge of those who had been appointed in a decree. Although the names of Professor Margarida Oliveira and the teacher Reginaldo Silva are listed as authors of the second version, both were not present at the final meetings of the Commission in April 2016. It happens that the second version of the curricular component History presented by the MEC to Brazilian society in May is not the one that

\footnotetext{
${ }^{2}$ They remained until the end of the works Antonio Ribeiro, Giovani Silva, Leandro Rocha, Leila Perussolo, Maria da Guia Medeiros, Marinelma Meireles, Rilma Melo and Tatiana Xavier.
} 
was delivered by the group that remained until the end of the work. There was even a "parallel" team working on a version that was presented in the Portal as having been drawn up by concierge-appointed professionals. So much so that in the document of the second version appear the names of two professionals of History with whom the official Commission never had contacts: Gabriela Pellegrino Soares (USP) and Pedro Paulo Abreu Funari (Unicamp).

Regarding the referees, the important contribution to the Commission's work in the unpublished version, which has been arbitrarily replaced by the "parallel" version, must be acknowledged: Flávia Eloisa Caimi (UPF), Luís Fernando Cerri (UEPG), Marcelo de Souza Magalhães (Unirio), Marieta de Moraes Ferreira (FGV), Martha Campos Abreu (UFF), Renilson Rosa Ribeiro (UFMT) and Sandra Regina Ferreira de Oliveira (UEL). Their names appear in the second version of the document published by the MEC in the Portal, unlike the names of Helenice Aparecida Bastos Rocha (Uerj) and Maria Helena Rolim Capelato (USP), who also issued opinions. Wilma de Nazaré Baía Coelho (UFPA) participated as a thinker for diversity issues and her name is also included in the document, as well as those of Antonio Daniel Marinho Ribeiro, Giovani José da Silva, Leandro Mendes Rocha, Leila Soares de Souza Perussolo, Maria da Guia de Oliveira Medeiros, Marinelma Costa Meireles, Rilma Suely de Souza Melo and Tatiana Gariglio Clark Xavier, who appear as the processors of the History proposal. However, it is firmly stated that the second version prepared by the Commission and supported by suggestions, criticisms, comments and opinions has been replaced by another, which is officially published as the second version by the MEC.

BNCC is for who anyway? Many criticisms received by the Commission were based on the idea that History teachers could not manage the proposal with their students. Were these teachers and scientific associations who criticized the first version really advocating the students' learning rights or merely defending and defending their own formation and their interests on the hegemonic and predominant historiographical tradition? Igor Salomão Teixeira and Nilton Mullet Pereira, referring to the controversies in the debates about BNCC and the Middle Ages in school curricula, pointed out that:

In November 2015 the Brazilian Association of Medieval Studies (ABREM) made available on its website a letter about the draft version of the BNCC and, among the criticisms on the choice of the committee responsible for the preparation of the document, the limited consultation timetable and the limitations to the members of the Board of Directors stated that the 
manifestation of ABREM is not a "defense" for the study of European History, nor a "conservative position" on the teaching of History. (TEIXEIRA; PEREIRA, 20I6, p. I8-I9)

The experience of the work in the BNCC Commission has shown that a thorough revision will be necessary in all dimensions of History Teaching, especially in teacher training courses in Brazil, structured in the quadripartite division and in the chronological beacons of political and/or economic events that construct colonial narratives that generate little (or no) pride and much prejudice.

\section{Reflections on teacher education in History: the professor historian}

It is interesting to note the movement created around the construction of the first version of the BNCC History document, especially by some scientific associations, such as ABREM and the Forum of Professionals of Ancient and Medieval History. Both were expressed in an open letter published by the National History Association (Anpuh) in which they were indignant at the exclusion of "contents" of Ancient and Medieval History, for example. In this and in other cases the students' right to learn was not discussed, but what would be done with the specialist teachers in these areas, if the BNCC were approved in the way it was elaborated. The delicate issue exposes one of the most serious problems of teacher education in Brazil: the ways in which history is learned in universities and colleges and the ways in which History in Basic Education is taught.

In addressing what a history teacher needs to know to teach competently the school curriculum component, Flávia Eloisa Caimi points out that it is necessary to:

[...] to focus on [...] three aspects to reflect on the nature of the [...] work [of the professor historian]: I) the knowledge to teach: history, historiography, epistemology and others; 2) the knowledge to teach: teaching, curriculum, didactics, school culture and others; 3) the knowledges of learning: student, cognition, historical thinking and others. (CAIMI, 2015, p. II2)

Apparently, item I (knowledge to teach), cited by the author, is presented as the most important to the undergraduate students in History. Item 2 (knowledge to teach) has been relegated to the Faculties of Education and teachers of Teaching Practice and Supervised Internship, while item 3 (learning skills) has not aroused the concern and 
interest in those who consider themselves "historians" and therefore more concerned with research than with teaching.

Much has already been discussed about the untying between teaching and research in Higher Education. There are even those who defend the idea that the researcher deals with History and the teacher should only deal with Teaching. It is not by chance that the following situation is easily found in undergraduate courses: a teacher of Medieval History, for example, teaches "content" of the academic discipline, but does not bother to teach teaching methodologies, concepts, procedures and attitudes for future teachers in training. After all, there would be so-called "pedagogical materials" and the disciplines of Teaching Practice and Supervised Internship, often viewed with disdain by those who consider themselves to be "historians". Considered of lesser prestige, these disciplines are often offered by teachers who do not have adequate pedagogical and historical / historiographic training.

The quadripartite model of History (Old, Medieval, Modern and Contemporary) continues to dominate the curricular matrices of undergraduate courses in History, from North to South of Brazil. Variations of this model can be found in the disciplines related to the History of Brazil (Colony, Empire and Republic) and in the way the courses are organized, generally following a chronology based on the political and economic transformations that occurred outside the American space. The Brazilian academics thus have contact with a historiography mainly French and little or nothing read about what is produced in History in Latin American countries, for example, that went through situations of colonialism similar to Brazil.

Thus, it is very common for academics of history to recognize the texts and ideas of Jacques Le Goff, George Duby, Jean Delumeau, and other French, but have never heard of the university during the formative years of Argentine, Mexican, and Chilean historians and other non-European nationalities. It is not surprising, then, that there are difficulties in understanding History outside a model enshrined at least since the nineteenth century, when Brazil appears to the world only after being "discovered" by Europeans. Colonialism has left its mark even in Brazilian universities, and even with the considerable increase in the number of postgraduate courses in History spread throughout the country, it is possible to verify a hierarchy in the Brazilian historiographical production, with the universities of the Center- South, notably USP (University of São Paulo), serving as a model and parameter from which ideas and people who make the "good" history emanate. 
What to do based on these findings, in addition to the criticism and the complaint about the change in the state in which the formation of History teachers in Brazil is located? In the first place, it will be necessary to review the model adopted almost a century ago of how history is studied and learned. It is possible that Old History, among other disciplines, still subsists in the curricula of the degrees for many years, but it would be possible to think that the professor of this academic discipline also took care of as it is taught, and it is learned Old History, either in Higher Education or Education Basic? It is known that undergraduate courses in History are "infested" with so-called "seminars", in which scholars in formation read texts and present them to the class, in addition to the teacher. This does not seem to be the best way to get rid of tasteless, bookish and meaningless teaching, but it will be just that way future teachers will do with their own students if changes are not implemented.

As they learned only "content" and not the ways to teach themselves and to learn concepts, attitudes and procedures, History teachers graduated in undergraduate courses will inevitably resort to the teaching materials that proliferate in public and private schools. Most of them will find the comfort of seeing the organized History as presented to them in Higher Education: between images and texts (BITTENCOURT, I998), the textbook pages defy a linear, chronological, evolutionary narrative, by stages of development, as if there were no diversity and multiple forms of societies relating to the environment and to each other. It is no wonder that contemporary Indian populations or groups living on the African continent today are treated as "primitive" or belonging to the "Stone Age." After all, if history with a capital $\mathrm{H}$ begins only with the emergence of writing, in so-called Ancient History, the staple populations that have a strong oral tradition would be out of History, in a "Prehistory" according to manuals and other teaching materials.

\section{Reflections on books and other didactic materials: the school's written history}

Books and other educational materials are big business in Brazil: they are sold in millions and used by teachers and students from North to South of the country, often as the only resource available in schools. There is a great financial investment in the production, distribution and evaluation of the History textbook in Brazil, however, there is no massive investment in the local production of states and municipalities. Local History is thus neglected in favor of a supposedly national and global history. The books still carry a generic narrative that would serve to explain the whole history of Brazil. The differences 
between the different regions (Amazonia, Center-South and Northeast) are erased and what one sees is a history articulated to the Rio-São Paulo-Minas axes, with the Northeast appearing only in the colonial period and the South in the period of migrations from the I9th century. Indigenous, African and Afro-descendant populations occupy specific places, in a linear sequence in which there are no simultaneities, parallels or juxtapositions, thus creating an imaginary of lazy and black and black natives affected only by manual labor.

Circe Bittencourt, however, warns that the use of teaching materials and the way in which their content will be taught and learned depends largely on the teacher's position:

Thus, the role of the textbook in school life may be the instrument of reproduction of ideologies and official knowledge imposed by certain sectors of power and the state. It is necessary to emphasize that the didactic book has several subjects in its elaboration process and it is through the intervention of teachers and students who carry out different practices of reading and school work. The uses that teachers and students make of the textbook are varied and can transform this ideological vehicle and source of profit of the publishers into a work tool more efficient and adapted to the needs of an autonomous teaching. The practices of reading the textbook are not identical and do not necessarily obey the rules imposed by authors and publishers or by governmental institutions. Thus, even considering that the textbook is characterized by the tax and directive text accompanied by prescriptive exercises, there are and there were diverse forms of use in which the teacher's performance is fundamental. (BITTENCOURT, 1998, p. 73-74)

Although the work of the teacher is fundamental, there is a serious problem to be faced in the use of textbooks of History: the presentation of only one possible version for the events, in this case, the interpretation of the author(s). The greatest difficulty for teachers of History is to present different versions, not only based on political facts, but combining them with the economy, religion, culture and other dimensions of human life. Most textbooks refer to kings, princes, emperors, monarchs, nobles, presidents, religious leaders, and politicians, but they do not deal with "ordinary people" (THOMPSON, I987; WILLIAMS, 1969). This explains, for example, the absence of poor and free men and women, which do not appear in the didactic narratives of Brazilian History. For many students (and unfortunately for some teachers), the period covered by black slavery in 
Brazil was lived only by two "categories" of people: white, free and wealthy men and black men, slaves and dispossessed. However, there are a myriad of people (men, women, male and female homosexuals, the elderly, children, indigenous people, free blacks, etc.) who do not appear in the stories told by books, which makes children, adolescents and young people do not understand their own history and feel themselves to be a minority, when, in fact, they constitute the majority of the population, obliterated and invisible in the didactic works.

Fernando Seffner, when reflecting on homosexuality in school and the difficulties in talking about what is considered "normal" in society, generating "majorities and" minorities, "notes that:

The notions of majority and minority are warlike metaphors, understood in the perspective of a geopolitics of attack and defense. Contrary to what human rights programs insist on at school, language is appropriate in a logic that values majority ownership to oppress the minority. Another element here is the distance between what is said, what is done and what is valued within the school, and what prevails in the "life out there". As discussed extensively in the educational literature [...], an important part of what is learned in school is seen as worthless in the "outside world", as well as a huge part of "outside world" knowledge and enters and is not problematized in school. (SEFFNER, 2013, p. 153)

The textbooks of History present a world of no value and meaning for poor, blacks, browns, homosexuals, students who do not recognize themselves or even in the transmitted images. Such images, for the most part merely illustrative, present distorted ideas that, if not properly contextualized by the teacher, teach preconceptions, stereotypes and crystallized conceptions that will hardly be deconstructed in school and out-of-school everyday. In addition, texts, activities and exercises strongly recommend excessive memorization and decontextualization. The use of questionnaires does not favor debates, the decolonization of curricula, creativity and the sensitivity of students and teachers. Thus, Eurocentrism gains space in the pages of books and other materials, where black and indigenous populations have little or no visibility. It is no wonder that Egypt appears (when it appears) as Africa's only legacy, along with a few lines dedicated to the emergence of early hominids. 
Anderson Oliva, studying textbooks from Brazil and Portugal between 1990 and 2005, comes to the following conclusions about the place occupied by Africa in the historical narratives presented by the analyzed materials:

\begin{abstract}
Already on the location of Egypt on the African continent, $86 \%$ of the books observed (six of the seven) made direct references to this aspect. At first, the theme seems to be redundant, or to cover up with obviousness. But we must not forget that Egypt's association with the "Fertile Crescent" has often become an element of greater resonance than the viewing of Egypt in Africa. Therefore, the explicit and direct citation of the geographical location of Egyptian civilization on the African continent is of great importance. Such an initiative, if worked out in a more revealing way by teachers and students, could arouse a greater interest in the subject and the formulation of questions that would bring them closer to the debates previously presented. (OLIVA, 2008, p. I90-I9I)
\end{abstract}

The problems encountered with regard to excluding historical narratives are not restricted to Africa. If the Americas derive exclusively from the ambition, covetousness, and greed of Europeans, who disputed territories overseas, it is almost impossible to carry out the study and perception of indigenous presence over time in the continent, as well as their struggles and resistance to all sorts of attempts at extermination and enslavement. In relation to enslaved African blacks and their descendants, the fact that their history was closed in the textbooks on May 13, I888, obliterates the struggles of the past and the present against racism and forms of discrimination and prejudice. If "race" is a notion created to classify human beings and was taken in the nineteenth century as absolute truth to explain European superiority and the inferiority of other peoples (Schwarz I993), the textbooks of History in Brazil continue to reproduce, at the beginning of the twenty-first century, narratives that make these populations invisible and naturalize, for example, ideas that black = African = slave indigenous $=$ primitive $=$ wild $=$ lazy .

The history of indigenous populations is treated only as the encounter / clash between "civilized" and "savage". The trajectory of the African and Afro-descendant populations, in turn, is studied only by the explanatory key of slavery. There are no references to other forms of resistance of black slaves other than the consecrated vision of quilombos, especially Quilombo dos Palmares. There were countless forms of resistance carried out by natives and blacks in the colonial period: fugues, capitulations, agreements, 
etc. It is even possible to refer to different forms of slavery, and not only to the classical ones, where corporal punishment prevailed in the relations of oppression between masters and captives. Without "slowing down" the enslavement of millions of Africans and their descendants in Brazil, textbooks could contribute to a better understanding of a story that has not yet been revealed in all its complexity and nuances.

Why not consider other ways of periodizing history in books and teaching materials? The history of Brazil, for example, could be told from the evidence of the presence of the first inhabitants of the Americas (30,000/II,000 years BC) until the arrival of Europeans at the end of the fifteenth century, which would be called History of Brazil Indigenous. The period from the fifteenth to the nineteenth century would receive the name of History of Brazil colonized by Europeans, especially Portuguese. From the sixteenth to the nineteenth century, juxtaposing itself to colonized Brazil (even to study the simultaneities that so much lack does to the didactic materials), one would study the History of Brazil enslaver. The nineteenth, twentieth and twenty first centuries could be called the History of Brazil diverse. We know that such periodization is subject to many criticisms, too, but it is only an example of what it is possible to propose something different from what has already become consecrated, canonical in books and other didactic materials.

Finally, there are no recipes and no formulas to solve the chronic problems verified in History Teaching in Brazil. However, it is reiterated that if the ubiquitous eurocentrism in curricula is not overcome (see discussions on the third version of $\mathrm{BNCC}^{3}$, in the training of teachers and textbooks, the racism in force in Brazilian society will not be combated for centuries. In addition to "content" that does not make sense and does not have meaning for students and teachers, the debates about what History we want in Brazilian schools and about the students' learning rights should point to changes in curriculum matrices, undergraduate courses and in the didactic production of History. All efforts must be made to achieve the greatest goals of History Teaching: that students and teachers historians know, understand, interpret, criticize and transform the world around them, denaturalizing it, deconstructing it and proposing "other worlds ".

\footnotetext{
${ }^{3}$ Available at <http://basenacionalcomum.mec.gov.br/\#/site/inicio >. Access in I5 mar. 2017.
} 


\section{Final considerations}

Referring to the racism present in History Teaching in Brazil is not the easiest task, because prejudices, as well as being veiled, are camouflaged in different lines, attitudes and situations. Whether in curricula, history teacher training courses or in books and other teaching materials, the Eurocentric view of history is still prevalent and naturalized among students and teachers. The process of deconstruction and overcoming racism in Brazilian schools will undergo a deep and necessary revision of the narratives presented to children, adolescents and young people, inside and outside the school environment. Discussions that involved the elaboration of the first version of the BNCC, for example, showed that there is still much to be done in tackling racism, and the publications of the second and (third) versions show how much still we are prejudiced about origins black and indigenous people of the country.

While the publishers were the voices that actually established the curricula, why was not there the general shout that there was the first version of History at the BNCC? When in Brazil will it break with the quadripartite division, blurring European history as the driving force behind Brazilian history? When will the universities actually consider the Basic Education teachers as partners, allies and not as mere reproducers of the scientific knowledge that emanates exclusively from them? How is it possible to imagine an education of ethnic-racial relations in Brazil with the national curriculum that has been designed, with teacher training courses completely alien to what happens in primary schools and with books and other teaching materials still loaded with so many stereotypes and prejudices? Many questions require more than ready and definitive answers: they ask for debates that problematize the status quo and that concern themselves with the learning rights of Brazilian children, adolescents and young people.

In contemporary Italy, for example, according to Professor Paolo Bianchini, of the Università degli Studi di Torino, a specialist in History of Education and textbooks, there is a strong movement that discusses the need to study the Roman Empire in History classes. According to Bianchini, it is more interesting to think of the uses and abuses that the political regime led by Benito Mussolini (1922-1943) made of the Empire, in order to convince the Italians to adhere to the fascist ideas. ${ }^{4}$ If a European country, like Italy, does

\footnotetext{
${ }^{4}$ In a conference entitled "The history of teacher training and citizenship in nineteenth and twentiethcentury Italy, with special attention to manuals", given at the First International Conference on Teaching History in the Amazon, held between 05 and July 09, 2016, at Ufopa (Universidade Federal do Oeste do Pará), in Santarém, Pará, Brazil.
} 
not insist that its students of basic education study such expensive content to teachers in Brazil, it is asked: is it important to take European History classes in Brazilian schools? What is the social relevance of the knowledge produced and reproduced by the professors historians? These and other questions point to the direction that teaching History in Brazil has not been teaching History of Brazil. This is because, as we have seen, a history of "Humanity" has been adopted for dates and events occurring outside the American continent, exclusive and prejudiced, in which otherness is treated through the "civilized" vs. "savage" binomial.

A query to any dictionary of the Portuguese language on the Internet ${ }^{5}$ to check the meanings of the word "pride", refers to at least two entries: "I. feeling of pleasure, of great satisfaction with one's own worth, with one's own honor. 2. pej. selfishness, admiration for one's own merit, self-love; arrogance, superb. "Taking the first meaning given by the dictionary, how can one imagine that a student has a sense of pleasure, of great satisfaction with his own worth, with his own honor, if everything he learns in History classes denies who he is? History classes teach that Brazil only "begins" with the arrival of the Portuguese "civilized" and that we owe them language, religion and other social and cultural aspects. The 2010 Census, however, points out that more than half of the current Brazilian population is not white (BRAZIL, 20IO), putting a check on this version of the facts. From the "savage" indigenous populations we inherit not only toponyms, but also the habit of daily bathing and the use of nets to sleep or rest. The point is that we do not know of other stories, because it insists on knowing only the narrative of the conquerors, European colonizers who subjugated the Others with much violence and the use of weapons, epidemics, etc.

The fact that these subjects are discussed at a time when the Brazilian public school is attacked in different ways ("School Without a Party", "New High School", etc.), shows how much still the debates about the curricula are still necessary, the training of historian teachers and the history textbooks. In a country that does not see itself as black, indigenous and from non-European populations, it is difficult to decolonize established and consecrated knowledge. The Brazilian Historical and Geographical Institute (IHGB), in its early nineteenth century, consolidated certain forms of writing the History of Brazil. It seems that Von Martius and Varnhagen, among others, have caused generations and generations of teachers and students of History to believe that the indigenous writers have

\footnotetext{
${ }^{5}$ Avaiable at <https://www.google.it/webhp?sourceid=chrome-instant\&ion=I\&espv=2\&ie=UTF8 \# $=$ significado+orgulho\&* $>$. Access in 15 mar. 2017.
} 
no history, only ethnography, besides disregarding the presence of Africans and Afrodescendants as protagonists in the the spatio-temporal trajectory of what Brazil has become. Between pride and prejudice, one writes and teaches a story painfully intertwined by the encounter/mismatch/reunion/confrontation of peoples from different parts of the world. The mirror of Herodotus shows a country that has a black face, indigenous features and carries in its body the marks of colonialism, slavery and displacements, in short, a walking metamorphosis.

\section{References}

BITTENCOURT, Circe. Textbooks between texts and images. In: BITTENCOURT, Circe (Org.). O saber histórico na sala de aula. São Paulo: Contexto, I998.

BOURDIEU, Pierre. A economia das trocas linguísticas: o que falar quer dizer. Translation by Sergio Miceli. São Paulo: Edusp, I996.

BRAZIL. Instituto Brasileiro de Geografia e Estatística. Censo demográfico 2000/ 2010. Brasília: IBGE, 20Io. Avaiable at <http://censo2oro.ibge.gov.br/>. Access in 25 jan. 2017. BRITO, Edson Machado de. O ensino de História como lugar privilegiado para o estabelecimento de um novo diálogo com a cultura indígena nas escolas brasileiras de nível básico. Fronteiras, Dourados, v. II, n. 20, p. 59-72, jul./ dez. 2009.

CAIMI, Flávia E. O que precisa saber um professor de História? História \& Ensino, Londrina, v. 2I, n. 2, p. I05-I24, jul./ dez. 2015.

CALAINHO, Daniela Buono; FERREIRA, Jorge; VAINFAS, Ronaldo; FARIA, Sheila de Castro. História. Doc. São Paulo: Saraiva, 2015. (4 vol.).

CHAUÍ, Marilena. Cultura e democracia: o discurso competente e outras falas. São Paulo: Moderna, I98I.

GATTI JÚNIOR, Décio. A escrita escolar da História: livro didático e ensino no Brasil (I97oI990). Bauru/ Uberlândia: Edusc/ Edufu, 2004.

MATTOS, Hebe. Sobre a BNCC e os historiadores. 2015. Avaiable at < https://conversadehistoriadoras.com/20I5/12/oI/sobre-a-bncc-e-os-historiadores/>. Access in 15 mar. 2017 .

MORENO, Jean Carlos. História na Base Nacional Comum Curricular: déjà vu e novos dilemas no século XXI. História \& Ensino, Londrina, v. 22, n. I, p. o7-27, jan./ jun, 2016.

OLIVA, Anderson Ribeiro. A História da África nos bancos escolares. Representações e imprecisões na literatura didática. Estudos Afro-Asiáticos, Ano 25, n. 3, p. 42I-46I, 2003. 
OLIVA, Anderson. Uma história esquecida. A abordagem da África Antiga nos manuais escolares de História: estudos de caso no Brasil e em Portugal (I990-2005). Em Tempo de Histórias, Brasília, n. 12, 2008.

ORTIZ, Renato (Org.). Pierre Bourdieu. Sociologia. São Paulo: Ática, I983.

PORTO, Ana Luiza Araújo. Entre práticas e saberes históricos: um diálogo entre o ensino de História Contemporânea e as teorias curriculares pós-críticas. In: SIMPÓSIO NACIONAL DE HISTÓRIA, XXIV, 2007, São Leopoldo. Anais... São Leopoldo: Unisinos, 2007 .

RUSSO, Kelly; PALADINO, Mariana. Reflexões sobre a lei II.625/ 2008 e a inclusão da temática indígena na escola. Gepiadde, Itabaiana, Year 08, Vol. I6, jul./ dec., 2014.

SCHWARCZ, Lilia K. M. O espetáculo das raças: cientistas, instituições e questão racial no Brasil, I870-I930. São Paulo: Companhia das Letras, 1993.

SEFFNER, Fernando. Sigam-me os bons: apuros e aflições nos enfrentamentos ao regime da heteronormatividade no espaço escolar. Educação e Pesquisa, São Paulo, v. 39, n. I, p. I45I59, jan./ mar. 2013.

TEIXEIRA, Igor Salomão; PEREIRA, Nilton Mullet. A Idade Média nos currículos escolares: as controvérsias nos debates sobre a BNCC. Diálogos, Maringá, v. 20, n. 3, p. I6-29, 2016.

THOMPSON, Edward P. A formação da classe operária inglesa. A árvore da liberdade. (Vol. I). Translation by Renato Busatto Netto. Rio de Janeiro: Paz e Terra, 1987.

VAINFAS, Ronaldo. A heresia dos índios: catolicismo e rebeldia no Brasil colonial. São Paulo: Companhia das Letras, 1995.

(Org.). América em tempo de conquista. Rio de Janeiro: Jorge Zahar, 1992. - Nova face do autoritarismo. 2015. Available at < http://oglobo.globo.com/opiniao/nova-face-do-autoritarismo-I8225777>. Access in 15 mar. 2017.

WILLIAMS, Raymond. Cultura e sociedade. Translation by Leônidas H. B. Hegenberg, Octany Silveira da Mota and Anísio Teixeira. São Paulo: Nacional, 1969.

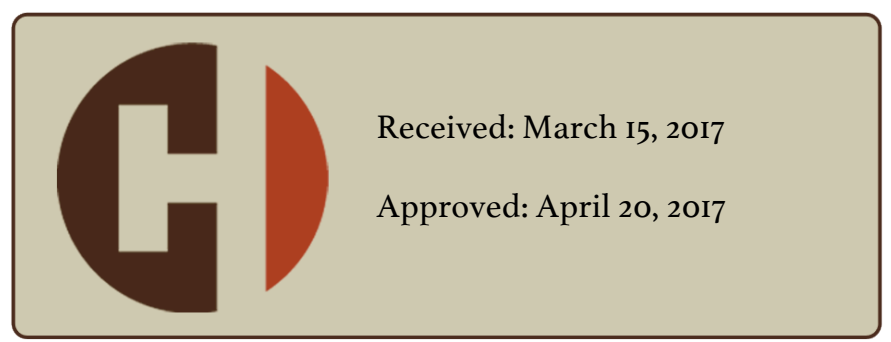

